\title{
Relationship between Career Decision, Self Efficacy and Vocational Identity among UiTM Shah Alam Generation Z
}

\author{
Hairul Fazzlinyana Mohd Harris \\ Career \& Counselling Centre, Universiti Teknologi MARA Malaysia, \\ Selangor, Malaysia
}

Asmah Ismail (Corresponding author)

Faculty of Educational Studies, Universiti Putra Malaysia, 43400 Selangor, Malaysia.

Received: Oct. 3, 2021 Accepted: Nov. 15, 2021 Online published: Nov. 22, 2021 doi:10.5296/ijhrs.v11i4S.19230 URL: https://doi.org/10.5296/ijhrs.v11i4S.19230

\begin{abstract}
The concept of career decision self-efficacy has been a topic of discussion for a long time and remains an important concept up to this day. Career counselling is effective in helping students in their career development. The current study examined the relationship between career decision self-efficacy and vocational identity. We followed the expectations of the Social Cognitive Career Theory (SCCT) and hypothesized that there is a significant relationship between career decision self-efficacy and vocational identity. We also studied the differences between genders on the two variables and the effect of career decision self-efficacy on vocational identity. The sample of the study comprised of 243 Generation Z participants from UiTM Shah Alam. The finding shows that there are no differences between genders on the career decision self-efficacy and female and vocational identity and female, which finding is in contrast to previous findings. The result of the study also shows that there is a significant relationship between career decision self-efficacy and vocational identity. The last finding shows a statistically significant result where career decision self-efficacy contributes significantly to vocational identity and career decision-making self-efficacy explains $13 \%$ of the variance in Vocational Identity. Therefore, this research provides information that can help to enhance students in the context of career counselling.
\end{abstract}

Keywords: career decision, self-efficacy, vocational identity 


\section{Introduction}

According to Pulevska-Ivanovska et al. (2017), the work-life balance plays a crucial role for Generation Z. In comparison to Generation Y, Generation Z is more determined about themselves (D'Silva et al., 2021). Generation $Z$ focuses on the values that benefit them rather than the company. They search for companies that can offer both career growth and experience through mentoring and a two-way communication. Generation Z does not hesitate to quit their jobs to accommodate to their family lives. They prefer to be in a flexible working environment where they have the ability to work part time in accord to them being able to also focus on their personal lives (Twenge et al., 2010). Lancaster and Stillman (2003) observed that Generation $\mathrm{Z}$ is more focused on their intrinsic motivations because they want the family life that they previously lacked - where their parents used to work too much resulting in them having less time to be at home.

A quote from Smitina (2010) mentions that Erikson states that the work-related identity is the most important aspect in creating the individuals' beliefs and obligations toward their career. Thus, vocational identity and career decision self-efficacy are seen as important aspects in looking at the way Generation $\mathrm{Z}$ approaches their career choice. They have a unique and distinctive character and work values. Based on the explanations on the differences between generations, the career decision making of Generation $\mathrm{Z}$ acquires a thorough look because employment is not just about the gaining of income, but also about the social statuses, and physical and mental activities.

This study used the Social Cognitive Career Theory (SCCT) that incorporates factors, such as the academic and career to understand career decision making (Mohd Rasdi \& Ahrari, 2020). Looking at the world as it is now, there are varying mixtures of different generations grouped together in the same organization. Each generation is different based on their own belief systems, goals, and aims that can highly affect each of their career achievement. The SCCT is an applicable theory in understanding the consequences of different generations because it encompasses different factors in career development, including culture, gender, background, upbringing, and age (Prawitasari, 2018).

The SCCT also examines self-efficacy beliefs of the different generations because their beliefs are different based on their own personal achievements. According to Renfro (2012), Generation $\mathrm{Z}$ is connected to others through social media and has a high IQ, resulting in them not needing a lot of supervision as they are good at finding their own information on the internet. He also mentions how Generation $\mathrm{Z}$ is more flexible and does not like to work in fixed office hours as they will be freelancers with specific expertise.

Earl et al. (2019) suggests that generation $\mathrm{Z}$ prefers to focus more on working environments, which is self-rule, requires multiple skills, valuable a role in a project from beginning to the end with a team that they can relate to. Due to that, they postulate the importance of self-efficacy for this generation in thinking of the long-term outcome of their career decision making (Earl et al., 2019). O'Brien et al. (2000) state how a low career decision-making self-efficacy may hinder individuals from trying new things, not seeking the right job that suits them, and having the tendency to lose hope easily. In this research, the right career 
choices of Generation $\mathrm{Z}$ was further explored. Generation $\mathrm{Z}$ is different in the aspects of their behaviors and needs. There is a lot more explorations that need to be done for career counsellors.

Thus in the world that is revolving and changing rapidly following the evolution of technology. The terms Volatile, Uncertain, Complex, and Ambiguous (VUCA) are amongst the important concepts for undergraduates to know before they venture into the workforce. Based on this situation, a lot of industries have mentioned that decision-making skills are important for undergraduates to acquire in order to increase their employability chances (Chelin et al., 2019).

In comparison to 30 years ago, many Malaysians nowadays have acquired a tertiary education. The number of graduates in Malaysia amounted to 341,311 in 2018 (Ministry of Education, 2019). With the revolution of the Industry 4.0, it is only fitting to see that many more graduates should come from the Science streams in order to fulfill the need of this revolution. According to the Ministry of Education (2019), majority of the graduates with a bachelor's degree in 2018 came from the field of Social Sciences, Business and Law with $48.9 \%$, followed by Engineering and Construction with $19.5 \%$, Science, Computer and Mathematics with $9.9 \%$, and Health bearing the percentage of $9.1 \%$. Overall, there appears to be more female graduates compared to male graduates $(\mathrm{F}=31,171 / \mathrm{M}=26,798)$ at the higher educational level - except in the field of engineering and construction where the number of male graduates is higher than female graduates.

Students in Malaysia mostly do not think thoroughly about their career choices. Many of them do not even have an in-depth career planning. They tend to focus more on academic achievements and career options are only realized towards the end of their studies. Thus, this creates a problem whereby they tend to follow the footsteps of other family members when it comes to choosing a career path (Sidek \& Bakar, 2020). Based on this finding, it is beneficial to see the career trend among the present Generation Z, particularly in how they make career decision and to see how this generation will enter the work force in the near future-frefer to the problem that deserves new research.

State why the problem deserves new research. For basic research, the statement about importance might involve the need to resolve any inconsistency in results of past work and/or extend the reach of a theoretical formulation. For applied research, this might involve the need to solve a social problem or treat a psychological disorder. When research is driven by the desire to resolve controversial issues, all sides in the debate should be represented in balanced measure in the introduction. Avoid animosity and ad hominem arguments in presenting the controversy. Conclude the statement of the problem in the introduction with a brief but formal statement of the purpose of the research that summarizes the materiat preceding it. For literature reviews as well as theoretical and methodological articles, also elearly state the reasons that the reported content is important and how the article fits into the eumulative understanding of the field. 


\section{Study Context}

Past research conducted in Malaysia found that Malaysian students are generally good in terms of academic achievements, but seem to be lacking in other skills, such as survival and critical thinking as well as frequently showing much insecurities about their abilities. A research conducted by Abdullah et al. (2018) identified important associations between self-knowledge and work-related search with career decision-makings. Another research by Sumari et al. (2019) focuses mostly on the role of family functioning on career decision-making self-efficacy. In UiTM Shah Alam, the trend of students joining career related programs seem to be declining. Thus, the current research focuses more on the career decision-making self-efficacy in order to explore its relationship with vocational identity in preparation of students' career life choices. The current research aimed to find out why the students at UiTM Shah Alam are still in a dilemma of what they are to pursue once graduated. Moreover, this research focuses on the members of Generation $\mathrm{Z}$ and how their Career Decision Self-Efficacy score has an effect on their vocational identities.

According to Collin (2006), the gender factor is not a popular research in career counselling. Nevertheless, past research has shown that female students scored high on positive characteristic and career decision self-efficacy beliefs (Koumoundourou et al., 2012). They have a firmer and more stable vocational identities. Scott and Ciani (2008) show that there are differences in career decision self- efficacy between men and women. Men seem to have a higher score, in general, than women when it comes to their vocational identities. On the other hand, in UiTM Shah Alam, there seems to be an equal number of inquiries based on gender-related to career-related issues. Therefore, the differences of gender in career decision self-efficacy and vocational identity need to be looked into as previous studies show that there is a contradiction in the results.

\section{Literature Review}

The concept of self-efficacy was taken from Bandura (1977) where it is believed that one can be led to perform a task much more successfully. The career self-efficacy is the measurement of self-efficacy based on the career behavior. Low self-efficacy may lead to disadvantages in career decision-making and development (Betz \& Hackett, 1986). A research conducted by Charokopaki and Argyropoulou (2019) shows that there is a correlation between being optimistic and making career decision self-efficacy. An optimistic nature in students' characteristics shows a higher level of confidence in handling conflicts and difficulties in decision-making skills. Additionally, it helps students to develop good career choices and personal confidence in dealing with obstacles and being more efficacious in the decision-making of career choices. The findings of Kim and Choi (2019) show how ethnic identity somewhat influences the correlation between inquisitiveness and career self-efficacy and how inquisitiveness seems to affect self-confidence in exploring and making career choices. The finding also shows that by learning more about their ethnic backgrounds, Asian Americans are more confident in seeking knowledge and making career choices.

Another study by Lam and Santos (2018) shows that a career course is deemed efficient when there seems to be a high career indecisions and decision-making difficulties (CDDs). One of 
the ways to reduce career indecisions and decision-making difficulties (CDDs) is by increasing the Career Decision Self -Efficacy (CDSE). The increase of the CDSE is very useful in decreasing the level of career indecision and CDD. The findings offer a few suggestions of how a career course based on the theory of career maturity can increase career decision self-efficacy and reduce career indecision and CDD. The result indicates a difference in the mean score of the Career Decision Self- Efficacy with the intervention implemented using the SCCT theory. The follow-up session after the completion of the intervention reveals a significant difference between the experimental group and the control group. Thus, it could be said that the SCCT intervention is a suitable form to be used in increasing the career decision-making self-efficacy (Rezaei et al., 2017).

Talib and Aun (2009) also mentioned in their research that the mean score of the undergraduate respondents in Malaysia is high in vocational identity. Nonetheless, the subscale of occupational information was found to be low for Malaysian undergraduates, putting the score barriers higher than before. Furthermore, the research found that there is no significant correlation between career indecision and vocational identity. There is a significant relationship between vocational identity and career indecision $(r=-.339, p \leq .01)$. Occupational information is seen as having a significant relationship with career indecision ( $\mathrm{r}$ $=-.223, \mathrm{p} \leq .01)$. Students who acquired a wide range of information on careers seem to make better career decisions. Career barrier also shows to be having a significant relationship with career indecisions for Malaysian undergraduate students $(r=-.199, \mathrm{p} \leq .01)$.

The study conducted by Galles and Lenz (2013) shows how students who had a high vocational identity score would have a much score on negative thinking and would be less prone to engage in any undesirable behaviour involving decision-making. When students have a set of distinctive and consistent ideas revolving around their vocational identity, they would be less likely to indulge in a series dysfunctional thought. This leads to them being able to make good career-based decisions and naturally steer the way to their desired career choices.

Jo et al. (2016) findings show a negative relationship between decision-making confusion (DMC) and vocational identity $(\mathrm{r}=-.60)$, between commitment anxiety $(\mathrm{CA})$ and vocational identity $(\mathrm{r}=-.68)$, and finally, between external conflict $(\mathrm{EC})$ and vocational identity $(\mathrm{r}=$ -.40). Thus, the relationship between career decision self-efficacy and vocational identity caused by the dysfunctional thoughts act as a mediator. The result of coefficients is significant with $\mathrm{p}<.01$.

Another research attempted to find out the relationship between educational and vocational identity. In this study, the focus of education is on the degree of commitment to education. The degree appears to be the medium with a deep exploration and recent educational commitment. The findings show that there is a relationship between educational and vocational identity among Romanian teenagers (Negru-Subtirica et al., 2018).

According to the research conducted by Li et al. (2019), there appears to be a relationship between the CDSE and Vocational Identity. There is a solid evidence that shows how the CDSE contributes to a higher vocational identity and how it is practically unchanged in a 
long span of time. When Vocational Identity is high, the CDSE would also be high. Therefore, this finding concludes that the relationship between CDSE and Vocational Identity is interrelated. This research also determined that the relationship between CDSE and Vocational Identity surpasses the socio-cultural aspect, as shown in the findings of the Shanghai and Hong Kong samples.

The research conducted by Galles et al. (2019) shows how decision-making correlates highly with the presence of vocational identity $(\mathrm{r}=.34)$. The detailed information on these aspects could help in incorporating a career-based decision making by decreasing the series of harmful and negative thinking when it comes to careers, while increasing the level of vocational identity. The result suggests that mindfulness could reduce the negative thinking of career-decision making, which would inevitably lead to a higher vocational identity. The finding further shows that positive thinking about career would lead to a high vocational identity and self-belief toward career goals, settings, and ambitions.

A research carried out in China shows that the career success criteria clarity (CSCC) has a significant correlation with CDSE, which indicates that individuals with a career goal can evaluate and assess their own selves and find out career-related information much more successfully (Xin et al., 2020). The study also mentions how having a good personality would lead them to have a clearer set of career goals. However, they also found how the family socio-economic has a positive relationship with the CDSE - in the interrelation to the vocational development.

In terms of gender influence on career, there are mixed findings on their performance on vocational identity. Betz and Hackett (1986) mention that men and women differ in their perception toward their capability in traditional work and modern work. The result of the male respondents is different from that of the females, with similar self-efficacy for both traditional and modern work. Female respondents, however, have a low self-efficacy for modern work as compared to traditional work. The abilities of both men and women are similar, and therefore, self-efficacy can be said to be affected by the nature of the work itself - traditional work or modern work - rather than of genders. Scott and Ciani (2008) found men to have a higher vocational identity than that of women. Both men and women had high scores of self-appraisals when identifying with their vocational identity. Equally, men and women have the belief that they could make career decisions that matched their vocational identity. Another study by Middleton (2017) indicates how women had a higher score of vocational identity than men. For men, being independent from their parents influenced them to become more goal-oriented in aiming for a career and also the skills needed to pursue it. The relationship of both men and women towards vocational identity is similar. For women, it also shows that a higher score of vocational identity reflects how they appear to be more confident about themselves.

Furthermore, Murniarti and Siahaan (2019) study in Indonesia shows that male undergraduates have a problem in making career-related decisions in comparison to female undergraduates. Moreover, male undergraduates seem to have a problem in finding information regarding career choices where they are more prone to receive many unrelated information about career and their tendency to be influenced by unreliable sources from 
social media. However, with a higher level of cognitive ability, they are also able to differentiate the information they receive. There are four hypotheses in this research which were:

$\mathrm{H}_{1}$. There is no significant difference between genders on vocational identity among the members of Generation Z in UiTM Shah Alam,

$\mathrm{H}_{2}$. There is no significant difference between genders on career decision self-efficacy among the members of Generation Z in UiTM Shah Alam,

$\mathrm{H}_{3}$. There is a significantly positive relationship between career decision self-efficacy and vocational identity among the members of Generation Z in UiTM Shah Alam, and

$\mathrm{H}_{4}$. There is no significant influence of career decision self-efficacy on vocational identity among the members of Generation Z in UiTM Shah Alam.

Ex post facto research was used in this study. This research used the criterion group study also known as the fundamental comparative study.

\section{Method}

\subsection{Participants and Procedure}

This research population was made up of the undergraduates from UiTM Shah Alam between the age range of 19 to 24 years old. Two faculties, namely, the Faculty of Applied Science and the Faculty of Law were chosen randomly using Excel. At the time of the study, the students registered at the Faculty of Applied Science were 3147 and for the Faculty of Law were 2074.

The sample size for the students was based on the table created by Cohen and Lea (2004). The sample size for Independent T-Test was 64, while for Multiple Regression, the independent variable was five, and thus, the sample size was 91. The sample size that was taken into consideration was 182, with 91 samples from each faculty, so that it would cover for both statistical analyses. The researcher managed to collect 243 and use that sample size as larger sample sizes give more reliable results with greater precision and power.

The faculty was chosen based on the random sampling used in Excel. This allowed the respondent to have an equal chance of being chosen for the research. The type of sampling used in this research was the cluster sampling. Cluster sampling allows the researcher to select a specific place - in this case, the researcher chose only UiTM Shah Alam as a sample. This type of sampling was used because it is suitable for a small-scale research. The limitation of this sampling is on the generalization of the research findings (Cohen et al., 2002).

The faculty was chosen based on random sampling using excel so that the respondent will have the equal chance of being in the research. This research is using the cluster sampling. By cluster sampling, the researcher selects a specific place, in this case the researcher chooses only UiTM Shah Alam as a sample. This type of sampling is used because it is suitable for small scale research. The limitation of this sampling is on the generalization of this research 
findings (Cohen et al., 2000).

\subsection{Instrumentation}

The study utilized two instruments to collect the data. The instruments include Career Decision Self- Efficacy Scale and the Vocational Identity. The Career Decision Self- Efficacy Scale (Short-form) was built by Betz et al. (2005) and My Vocational Situation was developed by Holland et al. (1980). In this research, the My Vocational Situation was used to measure Vocational Identity.

The Career Decision Self-Efficacy Scale (CDSE) is important in making career decisions and career development. Career decision self-efficacy was formerly defined by Taylor and Betz (1983) and Betz et al. (2005) as the confidence that one has in making the necessary action related to career decision. Career decision self-efficacy is measured in five areas, which are self-appraisal, gathering occupational information, goal selection, planning, and problem solving. The first CDSE developed consists of 50 items, but there is a new shorter version, which consists of 25 items that made the assessment easier. The short form was developed by taking out five out of the 10 items in the five parts. The item was maintained based on the generality of the content compared to an item, which is specific. The score for this instrument was obtained by summing up all the 25 questions. The minimum score for this instrument is 25 and the maximum score is 100. A higher score indicates the higher level of CDS. This scale represents a good psychometric value in terms of its reliability and validity. Most of the reliability and validity score of this scale were conducted based on college student participants (Luzzo, 1996). The reliability of the CDSE (Short-form) has an internal consistency of .73 for self-appraisal and .83 for goal selection and an overall of .94 alphas for all items. Another research shows that the reliability ranges from .69 (self-appraisal) to .83 (goal selection) and .93 for the overall score of all the items (Betz \& Luzzo, 1996). A conclusion of the CDSE shows an adequate reliability to be used in research (Luzzo, 1996).

The My Vocational Situation (MVS) was used to evaluate vocational identity (clear vocational goal), occupational information (enough information to make work related decisions) and obstacles in chasing vocational goals. The MVS is made up of 18 'true' and 'false' items, which measures the vocational identity and 8 'yes' or 'no' items, which measures occupational information and obstacles (Nitsch et al., 2017). The vocational identity items are divided into five categories. The first category is for anxiety comprising items $6,8,9,12$, and 18 . The second category is for confidence, covered by items $1,2,3,7$, 10, and 13. The third category is for self-assessment, which consists of items 4, 5, 15, and 16 . The fourth category consists of occupational information measures as in items 11 and 14, and lastly the fifth category belongs to the independent item, which is item 17 (Mauer \& Gysbers, 1990). Item number 19 consists of four sub-items that measured the occupational information and item number 20 also had four sub-items measuring the obstacles. According to Holland et al. (1980), the Vocational Identity has a very high internal consistency. Meanwhile, the Occupational Information and Barriers have a low internal consistency as it does not resemble a scale, but a checklist.

In this study, only the vocational identity questions were analyzed. The score for this 
instrument was obtained by summing up all the 18 questions, which were marked as the true answers. The minimum and maximum scores are 1 and 18. A higher score indicates a higher level of Vocational Identity.

The construct validity shows that the MVS has a positive correlation between age, and on the other hand the MVS is negatively correlated with vocational goals (Holland, 1980). The CDSE is also related to the MVS (Holland et al. 1980). In Betz and Luzzo (1996) research shows that there is a correlation between vocational identity and gender, which for women it ranges from .40 to .66 and for men it ranges from .28 to .56. Wanberg and Muchinsky (1992) shows that the Vocational Identity has a correlation with the indecision ranging from .70 to -.78 .

\subsection{Pilot Studies}

A total of 33 participants were asked to answer the Career Decision Self Efficacy Scale and the My Vocational Situation. The survey was distributed randomly among UiTM Shah Alam students. The result shows the reliability of the respected instruments.

Table 1. Reliability Statistics for Career Decision Self- Efficacy Scale and My Vocational Situation

\begin{tabular}{|c|c|c|c|}
\hline Instrument & Cronbach's $\alpha$ & $\begin{array}{c}\text { Cronbach's } \alpha \text { Based on Standardized } \\
\text { Items }\end{array}$ & N of Items \\
\hline CDSE & .943 & .946 & 25 \\
\hline MVS & .844 & .848 & 18 \\
\hline
\end{tabular}

Table 1 shows that the overall analysis of CDSE items shows a very good internal consistency reliability with Cronbach's $\alpha .943$. With the Cronbach's $\alpha$ that is higher than .7, there is no need for removing the item with low item total correlations. The MVS also shows a very good internal consistency reliability with Cronbach's Alpha .844 . With a Cronbach's Alpha that is higher than .7, there is no need for removing the item with low item total correlations.

\section{Results}

\subsection{Participants' Profile}

The descriptive data reported in this study are based on the final sample of 243 participants. They represented students from the Law Faculty $54.3 \%(\mathrm{n}=132)$ and Applied Science Faculty $45.7 \%(\mathrm{n}=111)$. The breakdown of the participants are presented according to gender, race, semester, and major. The participants consisted of $69.5 \%(n=169)$ females and $30.5 \%$ (74) males. The participants were divided into two main races, which are Malay who made up $94.2 \%(\mathrm{n}=229)$, while $5.8 \%(\mathrm{n}=14)$ were Sabah and Sarawak Bumiputera. In terms of their academic years, the participants represented Year 1 is $36.2 \%(\mathrm{n}=88)$, Year 2 is $49 \%(\mathrm{n}=119)$, Year 3 is $9.9 \%(\mathrm{n}=24)$ and Year 4 is $4.9 \%(\mathrm{n}=12)$. 
4.2 Means and Standard Deviations of Career Decision-Making Self-Efficacy Subscales and Vocational Identity

Table 2. Means and Standard Deviations of Career Decision Self-Efficacy Subscales and Vocational Identity

\begin{tabular}{|c|c|c|c|}
\hline Constructs & $\mathrm{N}$ & Mean & SD \\
\hline SA & 243 & 18.51 & 3.92 \\
OI & 243 & 18.38 & 3.18 \\
GS & 243 & 18.29 & 2.98 \\
PL & 243 & 17.71 & 3.15 \\
PS & 243 & 17.10 & 4.17 \\
VI & 243 & 24.28 & 4.22 \\
\hline
\end{tabular}

Note. Self-Appraisal=SA; Occupation Information=OI; Goal Selection=GS; Planning= PL; Problem Solving=PS; Vocational Identity=VI.

The CDSE-SF subscales show the mean score of all the participants is 18.51 with a standard deviation of 3.92 in Self-Appraisal, a mean score of 18.38 with a standard deviation of 3.18 in Occupational Information, a mean score of 18.29 with a standard deviation of 2.98 in Goal Selection, a mean score of 17.71 with a standard deviation of 3.15 in Career Planning, and a mean score of 17.10 with a standard deviation of 4.17 in Problem Solving. Thus, by looking at the five subscales, it can be concluded that the participants have a high Self-Appraisal followed by Occupational Information, Goal Selection, Career Planning, and Problem Solving. Meanwhile, for My Vocational Situation, the mean is 24.28 and the standard deviation is 4.22 .

It is understood that self-appraisal, occupational information, career planning, and goal selection is the phase for preparation to get into the career world. Thus, leaving Problem Solving in the later phase when they are in the working world. The result indicates that the mean for the first phase should be higher than that of the latter.

\subsection{Hypothesis Analyses}

This section reports the results of the data analyzed using three statistical measures: (1) Independent t-test, (2) Pearson correlation, and (3) Multiple regression to measure the relationship and effect between career decision-making self-efficacy and vocational identity. The Independent $t$-test was used to determine if there are any differences between the means among generation $\mathrm{Z}$ in terms of gender. The alpha level used was .05.

4.3.1 Hypothesis 1: There is no Significant Difference Between Genders in Career Decision Self-Efficacy Among Generation Z in UiTM Shah Alam

The Independent T-Test was used to answer Research Question 1: Is there any significant difference between gender in career decision self-efficacy among generation $\mathrm{Z}$ in UiTM Shah Alam? High scores on the CDSE-SF subscales indicate high levels of career decision-making self-efficacy, while low scores indicate low levels of career decision-making self-efficacy. 
The analysis shows that there is no significant difference between genders in career decision self-efficacy among generation Z in UiTM Shah Alam.

Table 3. Group Statistics Differences of Gender for CDSE-SF

\begin{tabular}{|c|c|c|c|c|}
\hline & Gender & $\mathrm{N}$ & Mean & SD \\
\hline CDSE-SF & Male & 74 & 90.23 & 14.40 \\
\cline { 2 - 5 } & Female & 169 & 89.88 & 13.93 \\
\hline
\end{tabular}

Table 4. Independent Samples Test for CDSE-SF

\begin{tabular}{|c|c|c|c|c|c|c|c|c|}
\hline & \multicolumn{2}{|c|}{$\begin{array}{c}\text { Levene's Test for } \\
\text { Equality of } \\
\text { Variances }\end{array}$} & \multicolumn{6}{|c|}{ t-test for Equality of Means } \\
\hline & \multirow[t]{2}{*}{$\mathrm{F}$} & \multirow[t]{2}{*}{ Sig. } & \multirow[t]{2}{*}{$\mathrm{t}$} & \multirow[t]{2}{*}{$\mathrm{df}$} & \multirow{2}{*}{$\begin{array}{l}\text { Sig. } \\
\text { (2-taile } \\
\text { d) }\end{array}$} & \multirow{2}{*}{$\begin{array}{c}\text { Mean } \\
\text { Differenc } \\
\mathrm{e}\end{array}$} & \multirow{2}{*}{$\begin{array}{l}\text { Std. Error } \\
\text { Differenc } \\
\mathrm{e}\end{array}$} & $\begin{array}{c}95 \% \text { CI of the } \\
\text { Difference }\end{array}$ \\
\hline & & & & & & & & UP \\
\hline EVA & .642 & .424 & .180 & 241 & .857 & .35399 & 1.96201 & -3.510894 .21887 \\
\hline EVNA & & & .178 & 135.256 & .859 & .35399 & 1.98747 & -3.576554 .28453 \\
\hline
\end{tabular}

Note. Equal variances assumed= EVA; Equal variances not assumed=EVNA.

The independent t-test was conducted to find out whether there is any difference between gender for career decision-making self-efficacy. The results in Table 4 show that there is no significant difference in the score for males $(\mathrm{M}=90.23, \mathrm{SD}=14.4)$ and female $(\mathrm{M}=89.88$, $\mathrm{SD}=13.93 ; \mathrm{t}(241)=.180, \mathrm{p}=.857$, two tailed $)$.

Table 5. Group Statistics Differences between Gender and CDSE-SF Subscale

\begin{tabular}{|c|c|c|c|c|}
\hline Construct & Gender & $\mathrm{N}$ & Mean & $\mathrm{SD}$ \\
\hline \multirow[t]{2}{*}{ SA } & Male & 74 & 18.20 & 3.03 \\
\hline & Female & 169 & 18.64 & 4.25 \\
\hline \multirow[t]{2}{*}{ OI } & Male & 74 & 18.40 & 3.44 \\
\hline & Female & 169 & 18.37 & 3.08 \\
\hline \multirow[t]{2}{*}{ GS } & Male & 74 & 18.58 & 2.76 \\
\hline & Female & 169 & 18.16 & 3.07 \\
\hline \multirow[t]{2}{*}{ PL } & Male & 74 & 17.80 & 3.42 \\
\hline & Female & 169 & 17.67 & 3.04 \\
\hline \multirow[t]{2}{*}{ PS } & Male & 74 & 17.26 & 3.47 \\
\hline & Female & 169 & 17.04 & 4.45 \\
\hline \multirow[t]{2}{*}{ VI } & Male & 74 & 24.05 & 4.20 \\
\hline & Female & 169 & 24.37 & 4.25 \\
\hline
\end{tabular}

Note. Self-Appraisal=SA; Occupation Information=OI; Goal Selection=GS; Planning= PL; Problem Solving=PS; Vocational Identity=VI. 
Table 6. Independent Samples Test Differences between Gender CDSE-SF

\begin{tabular}{|c|c|c|c|c|c|c|c|c|c|c|}
\hline & \multicolumn{2}{|c|}{$\begin{array}{l}\text { Levene's } \\
\text { Test for } \\
\text { Equality of } \\
\text { Variances }\end{array}$} & \multicolumn{7}{|c|}{ t-test for Equality of Means } \\
\hline & & \multirow[t]{2}{*}{$\mathrm{F}$} & \multirow[t]{2}{*}{ Sig. } & \multirow[t]{2}{*}{$\mathrm{t}$} & \multirow[t]{2}{*}{ df } & \multirow{2}{*}{$\begin{array}{c}\text { Sig. } \\
\text { (2-tailed } \\
\text { ) }\end{array}$} & \multirow{2}{*}{$\begin{array}{l}\text { Mean } \\
\text { Differenc } \\
\text { e }\end{array}$} & \multirow{2}{*}{$\begin{array}{c}\text { Std. Error } \\
\text { Differenc } \\
\text { e }\end{array}$} & \multicolumn{2}{|c|}{$\begin{array}{l}95 \% \text { CI of the } \\
\text { Difference }\end{array}$} \\
\hline & & & & & & & & & LO & UP \\
\hline SA & EVA & .329 & .567 & -.799 & 241 & .425 & -.436 & .546 & -1.512 & 639 \\
\hline & EVNA & & & -.908 & 190.89 & .365 & -.436 & .480 & -1.384 & .511 \\
\hline $\mathrm{OI}$ & EVA & 1.280 & .259 & .043 & 241 & .966 & .019 & .444 & -.856 & .895 \\
\hline & EVNA & & & .041 & 126.53 & .967 & .019 & .464 & -.899 & .937 \\
\hline$\overline{\mathrm{GS}}$ & EVA & .118 & .732 & 1.014 & 241 & .312 & .421 & .415 & -.397 & 1.240 \\
\hline & EVNA & & & 1.057 & 154.05 & .292 & .421 & .398 & -.365 & 1.208 \\
\hline$\overline{\mathrm{PL}}$ & EVA & 3.267 & .072 & .292 & 241 & .770 & .128 & .440 & -.738 & .995 \\
\hline & EVNA & & & .279 & 125.78 & .781 & .128 & .460 & -.783 & 1.040 \\
\hline PS & EVA & .094 & .760 & .380 & 241 & .704 & .221 & .581 & -.924 & 1.366 \\
\hline & EVNA & & & .419 & 176.36 & .676 & .221 & .528 & -.821 & 1.263 \\
\hline
\end{tabular}

Note. Self-Appraisal-SA; Occupation Information=OI; Goal Selection=GS; Planning= PL; Problem Solving=PS; Vocational Identity=VI; Equal variances assumed=EVA; Equal variances not assumed=EVNA.

The result for the subscales of CDSE for Self-Appraisal shows the score for males is $\mathrm{M}=$ 18.20, $\mathrm{SD}=3.03$ and for the females is $\mathrm{M}=18.64, \mathrm{SD}=4.25 ; \mathrm{t}(241)=-.799, \mathrm{p}=.425$, two tailed. Meanwhile for Occupation Information the score for males is $\mathrm{M}=18.40, \mathrm{SD}=3.44$ and female is $\mathrm{M}=18.37, \mathrm{SD}=3.08 ; \mathrm{t}(241)=.043, \mathrm{p}=.966$ two tailed. The Goal Selection score for males is $\mathrm{M}=18.58, \mathrm{SD}=2.76$ and for females is $\mathrm{M}=18.16, \mathrm{SD}=3.07 ; \mathrm{t}(241)=$ $1.014, \mathrm{p}=.312$ two tailed. The Planning scores for males is $\mathrm{M}=17.80, \mathrm{SD}=3.42$ and for female is $\mathrm{M}=17.67, \mathrm{SD}=3.04 ; \mathrm{t}(241)=.292, \mathrm{p}=.770$ two tailed, while for Problem Solving the score for males is $\mathrm{M}=17.26, \mathrm{SD}=3.46$ and for females $\mathrm{M}=17.04, \mathrm{SD}=4.45 ; \mathrm{t}$ $(241)=.380, \mathrm{p}=.704$ two tailed.

4.3.2 Hypothesis 2: There Is no Significant Difference Between Genders in Vocational Identity Among Generation Z in UiTM Shah Alam

The Independent T-Test was used to answer Research Question 2: Is there any significant difference between gender in Vocational Identity among generation Z in UiTM Shah Alam? High scores on the My Vocational Situation show high Vocational Identity, while low scores show low levels of Vocational Identity. The analysis shows that there is no significant difference between gender in Vocational Identity among generation Z in UiTM Shah Alam.

Table 7. Group Statistics Differences of Gender for Vocational Identity

\begin{tabular}{|l|c|c|c|c|}
\hline \multicolumn{1}{|c|}{ Construct } & Gender & $\mathrm{N}$ & Mean & SD \\
\hline \multirow{2}{*}{$\begin{array}{l}\text { Vocational } \\
\text { Identity }\end{array}$} & Male & 74 & 24.05 & 4.20 \\
\cline { 2 - 5 } & Female & 169 & 24.37 & 4.25 \\
\hline
\end{tabular}


Table 8. Independent Samples Test Differences of Gender for Vocational Identity

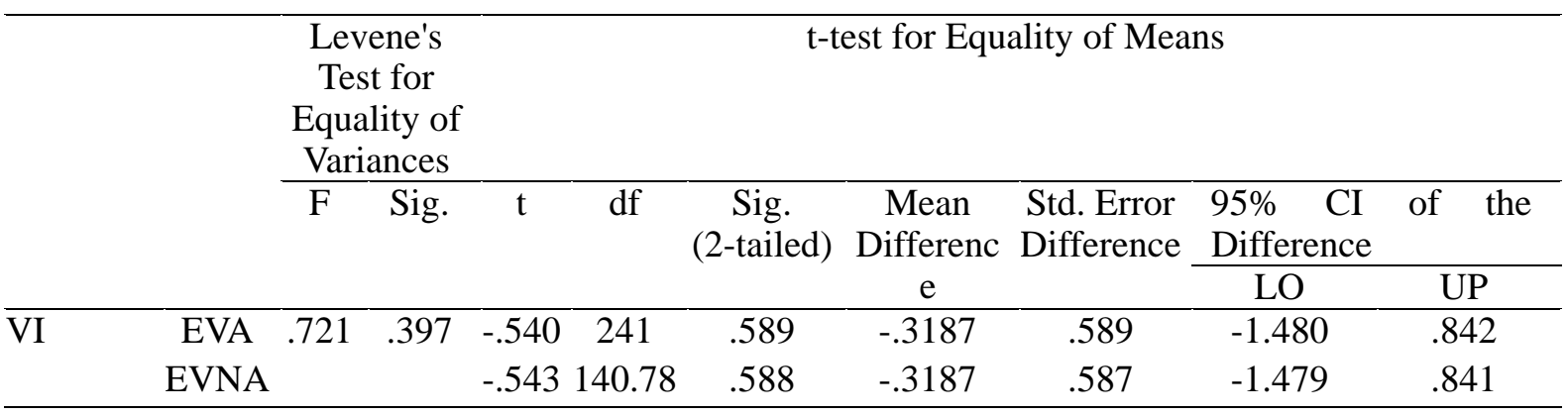

Note. Vocational Identity =VI; Equal variances assumed=EVA; Equal variances not assumed $=\mathrm{EVNA}$

The result for Vocational Identity based on Tables 8 and 9 shows the score for males is $\mathrm{M}=$ 24.05, $\mathrm{SD}=4.20$ and the score for females is $\mathrm{M}=24.37, \mathrm{SD}=4.25 ; \mathrm{t}(241)=-.540, \mathrm{p}=.589$, two tailed. In Conclusion, the result of mean comparison shows that there is no difference between gender in Career Decision Self-Efficacy as well as Vocational Identity on generation $\mathrm{Z}$.

4.3.3 Hypothesis 3: There Is a Significant Positive Relationship Between Career Decision Self-Efficacy and Vocational Identity Among Generation Z in UiTM Shah Alam

Pearson Correlation was used to answer Research Question 3: What is the relationship between career decision self-efficacy and vocational identity among generation $\mathrm{Z}$ in UiTM Shah Alam? High scores on the CDSE-SF subscales mean high levels of career decision self-efficacy, while low scores mean low levels of career decision-making self-efficacy. This is same as My Vocational Situation. A high score means high on vocational identity and low score means low on vocational identity. The relationship between CDSE-SF subscales and MVS shows that generation $\mathrm{Z}$ self-efficacy has a relationship with their vocational identity.

Table 9. Correlations between Career Decision Self Efficacy and Vocational Identity $(\mathrm{N}=243)$

\begin{tabular}{|c|c|c|c|}
\hline \multicolumn{2}{|l|}{ Constructs } & 1 & 2 \\
\hline \multirow[t]{2}{*}{ 1. CDSE } & Pearson Correlation & 1 & $.276^{* *}$ \\
\hline & Sig. (2-tailed) & & .000 \\
\hline \multirow[t]{2}{*}{ 2. $\mathrm{VI}$} & Pearson Correlation & $.276^{* *}$ & 1 \\
\hline & Sig. (2-tailed) & .000 & \\
\hline
\end{tabular}

Note. Career Decision Self-Efficacy=CDSE; Vocational Identity=VI. **. Correlation is significant at the 0.01 level (2-tailed).

From the table above, the result shows that there is a significant relationship between Career Decision Self-Efficacy and Vocational Identity $\mathrm{r}(243)=.276, \mathrm{p}<.05$. 
Table 10. Correlations between Career Decision Self Efficacy Subscales and Vocational Identity $(\mathrm{N}=243)$

\begin{tabular}{rll}
\hline \multicolumn{1}{c}{ Construct } & \multicolumn{1}{c}{ VI } \\
\hline \multirow{2}{*}{ SA } & Pearson Correlation & $.188^{* *}$ \\
\cline { 2 - 3 } & Sig. (2-tailed) & .003 \\
\multirow{2}{*}{ OI } & Pearson Correlation & $.196^{* *}$ \\
\cline { 2 - 3 } & Sig. (2-tailed) & .002 \\
\multirow{2}{*}{ GS } & Pearson Correlation & $.369^{* *}$ \\
\cline { 2 - 3 } & Sig. (2-tailed) & .000 \\
\multirow{2}{*}{ PL } & Pearson Correlation & $.263^{* *}$ \\
\cline { 2 - 3 } & Sig. (2-tailed) & .000 \\
\multirow{2}{*}{ PS } & Pearson Correlation & $.141^{*}$ \\
\cline { 2 - 3 } & Sig. (2-tailed) & .028 \\
\hline
\end{tabular}

Note. Self-Appraisal-SA; Occupation Information=OI; Goal Selection=GS; Planning= PL; Problem Solving=PS; Vocational Identity=VI; **. Correlation is significant at the 0.01 level (2-tailed); *. Correlation is significant at the 0.05 level (2-tailed).

Table 10 shows the positive relationship between Career Decision Self Efficacy Subscales and Vocational Identity. There is a significant relationship between the five subscales of Career Decision Self Efficacy and Vocational Identity. The findings show that Self-Appraisal has a small relationship with vocational identity with $\mathrm{r}(243)=.188, \mathrm{p}<.05$, Occupational Information also has a small relationship $\mathrm{r}(243)=.196, \mathrm{p}<.05$, while Goal Setting has a medium relationship with vocational identity with $\mathrm{r}(243)=.369, \mathrm{p}<$. 05. The Planning subscale has a small relationship with Vocational identity with $\mathrm{r}(243)=.263, \mathrm{p}<.05$ and Problem Solving also has a small relationship with vocational identity with $\mathrm{r}(243)=.141, \mathrm{p}$ <. 05 .

In summary, the result indicates that there is a significant relationship between career decision self-efficacy and vocational identity, however, referring to the strength of the relationship, it shows that the relationship is small and only one subscale of the CDSE, which is Goal Setting that is moderate. This strength is mentioned by Cohen (2004) that .5 is a large $\mathrm{r}, .3$ is moderate, and .1 is small.

4.3.4 Hypothesis 4: There Is a Significant Influence of Career Decision Self-Efficacy on Vocational Identity Among Generation Z in UiTM Shah Alam.

Standard multiple regressions were used to answer Research Question 4: Is there any influence of career decision self-efficacy on vocational identity among generation Z in UiTM Shah Alam? Career decision-making self-efficacy subscale was measured as a separate variable. The results of the multiple regression analyses are presented in Table 11. 
Table 11. Summary of Multiple Regression of the Career Decision-Making Self-Efficacy on Vocational Identity Analysis Assessing the Effects

\begin{tabular}{ccc}
\hline Constructs & B & Sig. \\
\hline SA & -.023 & .777 \\
OI & -.202 & .141 \\
GS & .647 & .000 \\
PL & .141 & .337 \\
PS & -.084 & .272 \\
\hline
\end{tabular}

Note. Self-Appraisal-SA; Occupation Information=OI; Goal Selection=GS; Planning= PL; Problem Solving=PS; Vocational Identity=VI

The result shows that Career Decision-Making Self-Efficacy contributes to Vocational Identity with a statistically significant result $($ Sig. $=.000 ; \mathrm{p}<.0005)$. The Adjusted R square shows that Career Decision-Making Self-Efficacy explains $13 \%$ of the variance in Vocational Identity. Based on Table 11, the strongest unique contribution to Vocational Identity in beta coefficient (B) is Goal Setting (.647). This result suggests that generation $\mathrm{Z}$ who has a good Goal Setting will contribute to knowing their Vocational Identity. The second largest beta coefficients (B) is Occupational Information (-.202). Next is Planning with the beta coefficients (B) of -.141. The fourth largest beta coefficients (B) is Problem Solving (-.084). The last unique contributor to Vocational Identity is Self-Appraisal with beta coefficients (B) of -.023 .

In conclusion, the significant result suggests that Career Decision Self-efficacy contributes to vocational identity, but only with $13 \%$, and this suggests that there are many other factors that contribute to generation $\mathrm{Z}$ vocational identity.

\section{Discussion}

As discussed by Betz and Hackett (1981), there are differences between gender. Similar findings with the study by Middleton (2017), which indicates that women tend to have a higher score of vocational identity than men. Koumoundourou et al. (2012) research also shows that female students score higher on positive characteristic and career decision self-efficacy beliefs. Another research conducted by Scott and Ciani (2008) shows that there are differences in career decision self- efficacy between men and women where men have higher scores than that of women in regard to their vocational identities. The current research shows contradicting findings where the new generation, especially female students are equally able to make decisions and decide based on their vocational identity as male students. According to the result in this study, it shows that both CDSE and Vocational Identity bear no difference between genders for the members of Generation Z in UiTM Shah Alam. Previous studies also show that the Self-Appraisal score is generally higher for women in relation to Vocational Identity, but proves dissimilar to the current findings. The current findings show that the five subscales of CDSE also do not show any difference between gender. Based on these findings, it is important to look at the differences in gender on career decision self-efficacy and vocational identity because it indicates that female students of Generation $\mathrm{Z}$ 
are more open and able to dictate their own vocational identities at an earlier age. They also receive support from others in reaching their aims or in achieving their vocational identities. Additionally, female students already have a target in mind on what they want to be, and they will gladly pursue it. Moreover, female students do not rely much on their passion when studying certain topics, yet they thrive anyway so that they could make their parents proud or successfully be the breadwinner for their families. The role of providing for the family is different in the past and present worlds. Nowadays, many female students carry the responsibilities of having to take care of their families; a role in which independent of the traditional and stereotypical norm held on by men in the past. Many of the female students also have a lot of information and support from others in order to excel in the working world. These factors empower female students and therefore is reflected in the score of the career decision self-efficacy and vocational identity. Thus, the factors such as the family and the environment play a role in influencing the score of this finding where it shows no significant difference between genders in career decision self-efficacy and vocational identity. Koumoundourou et al. (2012) mention that regardless of genders, students know that they are able to make a career decision besides having a strong idea about their vocational identity. This finding supports the statement made by Koumoundourou et al. (2012). Gender does not play a role in Generation $\mathrm{Z}$ career decision self-belief and vocational identity.

The result on the relationship of career decision self-efficacy and vocational identity is similar with previous findings of past studies (Galles et al., 2019; Gushue et al., 2006; Johnson et al., 2014; Li et al., 2019; Mohd Rasdi et al., 2021). Based on Gushue et al. (2006), there is a significant relationship between the two in African American students. This research also determines that the relationship between CDSE and Vocational Identity surpasses the socio-cultural aspect because self-belief is important for humans regardless of their races. The study of Abdullah et al. (2018) shows that it is important to have self-efficacy in order for them to know about their vocational identity. This self-efficacy is important for students to make important decision in deciding on their vocational identity. The research conducted in Malaysia found that Malaysian students are good in terms of academic achievements, but they are generally not confident in deciding for their own careers. Furthermore, when self-confidence increases, students will engage in a much more proactive behaviors and coincidentally will also easily know what their interests might be. Therefore, with this finding, it shows that vocational identity is important in students who have low scores in the CDSE scale to enhance the career decision self-efficacy and consequently their vocational identity. Quoted from Smitina (2010) who mentions that Erikson states that the work-related identity is the most important aspect in creating individuals' beliefs and obligations toward their careers. The vocational identity as well as the career decision self-efficacy are seen as an important aspect in looking at the Generation Z students in UiTM Shah Alam when approaching their career choices. They have a unique and distinctive set of characters as well as work values. It gives an individual a clear direction in life and the determination in human development process (Rezaei et al., 2017). Thus, with this finding it can help the students of UiTM Shah Alam to increase their career decision self-efficacy so that they will have a much clearer vocational identity. The problem regarding the low number of students attending career related activities can be reduced when the career self-efficacy of 
Generation Z in UiTM Shah Alam increases.

Although the findings show a significant relationship, the degree, this relationship is small according to Cohen for the career decision self-efficacy subscales except for Goal Setting. This indicates that Goal Setting is important in creating vocational identity. A further analysis of multiple regression was used to find out the extend of how CDSE influences vocational identity. Jo et al. (2016) in their finding shows that career decision self-efficacy has an influence on vocational identity. Their findings are similar with the finding of the current study. The current finding shows that there is a significant result in the analysis and that $13 \%$ of career decision self-efficacy contributes to the vocational identity of the members of Generation Z.

The findings also show that Goal Setting is the largest contributor to vocational identity. This is in line with the analysis of correlation where Goal Setting has the moderate strength with vocational identity. In relation to this finding among the students of UiTM Shah Alam, it shows the good idea they would achieve after graduating. The findings also show that occupational information is the second highest score that influences vocational identity. Based on this, it can be said that they receive some good occupational information from the university itself along with other sources needed in developing their vocational identities.

The self-efficacy and its effect towards behavior is shown in this research where it is portrayed in the Generation Z vocational identity. The third element of SCCT is career goals; in which individuals used as a guide to achieve their ambitions. Career goal can be seen as related to goal setting, and thus, this theory is supported by this research. With a goal setting, students are more confident in their vocational identity. Thus, it can be said that the SCCT theory is applicable to the students of Generation Z in UiTM Shah Alam.

\section{Recommendation}

The findings in this study show that the self-efficacy of Generation $\mathrm{Z}$ students in career-related task is small to moderate only. This result suggests that there is a need to help students increase their career decision self-efficacy so they can avoid having any difficulty in choosing a career path. This finding also shows that self-efficacy is an important element in making career-related decisions and developing vocational identity. Students who have issues when making a career decision and in vocational identity can take advantage of the intervention related to career self-efficacy. A career counselor, as suggested in the counsel of the SCCT theory, can develop intervention programs for students in their respective universities as the setting acts as a stepping-stone into the working world. The results of the current study reveal that goal setting contributes to a large amount in vocational identity. A counsellor should explore more on the effective intervention methods to improve students' abilities to develop a proper career goal and consequently a good career development process.

Counselors can use this finding to understand the importance of Generation Z's career decision self-efficacy and vocational identity before looking at it in a much deeper level in an before venturing to increase their career decision self -efficacy and then have a clear vocational identity. Counsellors are recommended to consider other factors, such 
as the students' family and environmental aspects in order to develop a stronger level of self-efficacy as a whole.

Future studies should look further into other variables that contribute to the relationship between the career decision self-efficacy and vocational identity because only $11 \%$ of variance contributes to vocational identity. The ethnic group for the participants of this study were mainly Malays and only a few Bumiputera of Sabah and Sarawak. Hence, future studies should focus more on the ethnics of Bumiputera Sabah and Sawarak. This study only focuses on the students of UiTM Shah Alam campus. Therefore, future studies should be conducted based on a wider population, such as the educational sector of private schools as well as government private-based universities.

\section{References}

Abdullah, N., Hussin, N., Shonubi, O. A., Ghazali, S. R., \& Talib, M. A. (2018). Career Decision-Making Competence, Self-Knowledge, and Occupational Exploration: A Model for University Students. Journal of Technical Education and Training, 10(1), 71-81. https://doi.org/10.30880/jtet.2018.10.01.006

Bandura, A. (1977). Social Learning Theory. Prentice.

Betz, N. E., \& Hackett, G. (1986). Applications of self-efficacy theory to understanding career choice behavior. Journal of Social and Clinical Psychology, 4(3), 279-289. https://doi.org/10.1521/jscp.1986.4.3.279

Betz, N. E., \& Luzzo, D. A. (1996). Career assessment and the career decision-making self-efficacy scale. Journal of Career Assessment, 4(4), 413-428. https://doi.org/10.1177/106907279600400405

Betz, N. E., Hammond, M. S., \& Multon, K. D. (2005). Reliability and validity of five-level response continua for the Career Decision Self-Efficacy Scale. Journal of Career Assessment, 13(2), 131-149. https://doi.org/10.1177/1069072704273123

Charokopaki, A., \& Argyropoulou, K. (2019). Optimism, Career Decision Self-Efficacy and Career Indecision among Greek Adolescents. Education Quarterly Reviews, 2(1), 185-197. https://doi.org/10.31014/aior.1993.02.01.52

Chelin, N., Matthiasdottir, G., Serreau, Y., Tudela, L., Rouvrais, S., \& Jordan, K. (2019). To embrace career decision making in STEM education. 11th International Conference on Education and New Learning Technologies, 3058-3066. https://doi.org/10.21125/edulearn.2019.0827

Cohen, B. H., \& Lea, R. B. (2004). Essentials of statistics for the social and behavioral sciences (Vol. 3). John Wiley \& Sons.

Cohen, L., Manion, L., \& Morrison, K. (2002). Research methods in education (6th ed.). routledge. https://doi.org/10.4324/9780203224342 
D’Silva, J. L., Ismail, I. A., Dahalan, D., Zaremohzzabieh, Z., \& Krauss, S. E. (2021). Insights into Developing 3D Visualization Technology to Enhance Gen Y Engagement in Agriculture. International Journal of Academic Research in Business and Social Sciences, 11(15), 185-196. https://doi.org/10.6007/IJARBSS/v11-i15/10645

Earl, J., Iskandar, F., \& Elizondo, F. (2019). Take a job, any job: Exploring the importance of matched interests to career paths and work satisfaction. Journal of Employment Counseling, 56(1), 33-45. https://doi.org/10.1002/joec.12101

Galles, J. A., \& Lenz, J. G. (2013). Relationships among career thoughts, vocational identity, and calling: Implications for practice. The Career Development Quarterly, 61(3), 240-248. https://doi.org/10.1002/j.2161-0045.2013.00052.x

Galles, J., Lenz, J., Peterson, G. W., \& Sampson Jr, J. P. (2019). Mindfulness and decision-making style: Predicting career thoughts and vocational identity. The Career Development Quarterly, 67(1), 77-91. https://doi.org/10.1002/cdq.12164

Gushue, G. V., Clarke, C. P., Pantzer, K. M., \& Scanlan, K. R. (2006). Self-efficacy, perceptions of barriers, vocational identity, and the career exploration behavior of Latino/a high school students. The Career Development Quarterly, 54(4), 307-317. https://doi.org/10.1002/j.2161-0045.2006.tb00196.x

Holland, J. J., Gottfredson, D. C., \& Power, P. G. (1980). Some diagnostic scales for research in decision making and personality: Identity, information, and barriers. Journal of Personality and Social Psychology, 39(6), 1191-1200. https://doi.org/10.1037/h0077731

Jo, H., Ra, Y.-A., Lee, J., \& Kim, W. H. (2016). Impact of dysfunctional career thoughts on career decision self-efficacy and vocational identity. The Career Development Quarterly, 64(4), 333-344. https://doi.org/10.1002/cdq.12069

Johnson, P., Schamuhn, T. D., Nelson, D. B., \& Buboltz Jr, W. C. (2014). Differentiation levels of college students: Effects on vocational identity and career decision making. The Career Development Quarterly, 62(1), 70-80. https://doi.org/10.1002/j.2161-0045.2014.00071.x

Kim, Y. H., \& Choi, N.-Y. (2019). Career decision self-efficacy of Asian American students: The role of curiosity and ethnic identity. The Career Development Quarterly, 67(1), 32-46. https://doi.org/10.1002/cdq.12161

Koumoundourou, G. A., Kounenou, K., \& Siavara, E. (2012). Core self-evaluations, career decision self-efficacy, and vocational identity among Greek adolescents. Journal of Career Development, 39(3), 269-286. https://doi.org/10.1177/0894845310397361

Lam, M., \& Santos, A. (2018). The impact of a college career intervention program on career decision self-efficacy, career indecision, and decision-making difficulties. Journal of Career Assessment, 26(3), 425-444. https://doi.org/10.1177/1069072717714539

Lancaster, L., \& Stillman, D. (2003). Tips on minimizing generational collisions. Reflections on Nursing Leadership, 29(1), 10-12. 
Li, M., Fan, W., Cheung, F. M., \& Wang, Q. (2019). Reciprocal associations between career self-efficacy and vocational identity: A three-wave longitudinal study. Journal of Career Assessment, 27(4), 645-660. https://doi.org/10.1177/1069072718796035

Luzzo, D. A. (1996). A psychometric evaluation of the career decision-making self-efficacy scale. Journal of Counseling \& Development, 74(3), 276-279. https://doi.org/10.1002/j.1556-6676.1996.tb01865.x

Mauer, E. B., \& Gysbers, N. C. (1990). Identifying career concerns of entering university freshmen using My Vocational Situation. The Career Development Quarterly, 39(2), 155-165. https://doi.org/10.1002/j.2161-0045.1990.tb00836.x

Middleton, J. J. (2017). The mediating influence of career aspirations and career decision-making self-efficacy on self-differentiation, vocational identity, and career indecision [PhD Thesis]. Louisiana Tech University.

Ministry of Education. (2019). Maklumat asas pendidikan [Basic educational information]. Ministry of Education.

Mohd Rasdi, R., \& Ahrari, S. (2020). The applicability of social cognitive career theory in predicting life satisfaction of university students: A meta-analytic path analysis. Plos One, 15(8), 1-22. https://doi.org/10.1371/journal.pone.0237838

Mohd Rasdi, R., Zaremohzzabieh, Z., \& Ahrari, S. (2021). Financial Insecurity during the COVID-19 Pandemic: Spillover Effects on Burnout-Disengagement Relationships and Performance of Employees Who Moonlight. Frontiers in Psychology, 12, 1-14. https://doi.org/10.3389/fpsyg.2021.610138

Murniarti, E., \& Siahaan, L. I. (2019). Millennials' Career Decision-Making Difficulties (CDMD) IN Indonesian University Students. Advances in Social Sciences Research Journal, 6(9), 268-276. https://doi.org/10.14738/assrj.69.7079

Negru-Subtirica, O., Pop, E. I., \& Crocetti, E. (2018). Good omens? The intricate relations between educational and vocational identity in adolescence. European Journal of Developmental Psychology, 15(1), 83-98. https://doi.org/10.1080/17405629.2017.1313160

Nitsch, K. P., Pedersen, J., Miliotto, A., Petersen, B., Robbins, S., Garcia, A., Hoisington, M. A., Smiley, J., \& Janikowski, T. (2017). My Vocational Situation (MVS): Case example and psychometric review. American Journal of Occupational Therapy, 71(2), 1-4. https://doi.org/10.5014/ajot.2017.025288

O’Brien, K. M., Bikos, L. H., Epstein, K. L., Flores, L. Y., Dukstein, R. D., \& Kamatuka, N. A. (2000). Enhancing the career decision-making self-efficacy of upward bound students. Journal of Career Development, 26(4), 277-293. https://doi.org/10.1177/089484530002600404

Prawitasari, G. (2018). The influence of generations on career choice (Social Cognitive Career Theory Perspective). 1st ASEAN School Counselor Conference on Innovation and Creativity in Counseling. https://doi.org/10.24036/02018718464-0-00 


\section{Macrothink}

International Journal of Human Resource Studies

ISSN 2162-3058

2021, Vol. 11, No. 4S

Pulevska-Ivanovska, L., Postolov, K., Janeska-Iliev, A., \& Magdinceva Sopova, M. (2017). Establishing balance between professional and private life of generation Z. Research in Physical Education, Sport and Health, 6(1), 3-10.

Renfro, A. (2012). Meet Generation Z. Getting Smart. http://gettingsmart.com/2012/12/meet -generation-z/

Rezaei, A. S., Shafiabady, A., \& Nejhad, M. R. F. (2017). The Effectiveness Instruction of the Savikas Career Construction Theory (SCCT) on the Career Decision-Making Self-Efficacy of the Unemployed Jobseekers Supported by Unemployment Insurance. International Journal of Psychology, 11(2), 48-78.

Scott, A. B., \& Ciani, K. D. (2008). Effects of an undergraduate career class on men's and women's career decision-making self-efficacy and vocational identity. Journal of Career Development, 34(3), 263-285. https://doi.org/10.1177/0894845307311248

Sidek, M. S., \& Bakar, A. Y. A. (2020). Emotional intelligence and self-efficacy career decision making among high school students. Education and Social Sciences Review, 1(1), $1-7$.

Smitina, A. (2010). The link between vocational identity, study choice motivation and satisfaction with studies. Procedia-Social and Behavioral Sciences, 5, 1140-1145. https://doi.org/10.1016/j.sbspro.2010.07.250

Sumari, M., Baharudin, D. F., Md Khalid, N., Ibrahim, N. H., \& Ahmed Tharbe, I. H. (2019). Family functioning in a collectivist culture of Malaysia: A qualitative study. The Family Journal. https://doi.org/10.1177/1066480719844334

Talib, M. A., \& Aun, T. K. (2009). Predictors of career indecision among Malaysian undergraduate students. European Journal of Social Sciences, 8(2), 215-224.

Taylor, K. M., \& Betz, N. E. (1983). Applications of self-efficacy theory to the understanding and treatment of career indecision. Journal of Vocational Behavior, 22(1), 63-81. https://doi.org/10.1016/0001-8791(83)90006-4

Twenge, J. M., Campbell, S. M., Hoffman, B. J., \& Lance, C. E. (2010). Generational differences in work values: Leisure and extrinsic values increasing, social and intrinsic values decreasing. Journal of Management, 36(5), 1117-1142. https://doi.org/10.1177/0149206309352246

Wanberg, C. R., \& Muchinsky, P. M. (1992). A typology of career decision status: Validity extension of the vocational decision status model. Journal of Counseling Psychology, 39(1), 71-80. https://doi.org/10.1037/0022-0167.39.1.71

Xin, L., Tang, F., Li, M., \& Zhou, W. (2020). From school to work: Improving graduates' career decision-making self-efficacy. Sustainability, 12(3), 1-16. https://doi.org/10.3390/su12030804 


\section{Macrothink}

International Journal of Human Resource Studies

ISSN 2162-3058 2021, Vol. 11, No. 4S

Zaini, S. N. M., Rami, A. A. M., Arsad, N. M., \& Anuar, M. A. M. (2021). Relationship of Academic Performance and Academic Self-Concept with Career Decision-Making among UPM Undergraduate Students. Asian Journal of University Education, 17(2), 50-61. https://doi.org/10.24191/ajue.v17i2.13403

\section{Copyright Disclaimer}

Copyright for this article is retained by the author(s), with first publication rights granted to the journal.

This is an open-access article distributed under the terms and conditions of the Creative Commons Attribution license (http://creativecommons.org/licenses/by/4.0/). 